\title{
ミニレビュー
}

\author{
70 年ぶりのデング熱国内流行と将来予想 \\ 第 67 回日本衛生動物学会緊急シンポジウム（市民講座） \\ 金沢大学宝町キャンパス：2015年3月28日（土） \\ 一はじめに一 \\ 沢辺京子* \\ 国立感染症研究所昆虫医科学部（干162-8640 東京都新宿区戸山 1-23-1）
}

（受領：2015年 8 月 13 日；登載決定：2015年 10月 17 日）

\section{Autochthonous dengue outbreak in Japan after a blank of 70 years and the future prediction of such cases}

\author{
-Introduction- \\ Kyoko SAWABE* \\ *Corresponding author: sawabe@nih.go.jp \\ Department of Medical Entomology, National Institute of Infectious Diseases, \\ Toyama 1-23-1, Shinjuku-ku, Tokyo 162-8640, Japan
}

(Received: 13 August 2015; Accepted: 17 October 2015)

\begin{abstract}
A total of 162 autochthonous dengue cases were reported in Japan in 2014, after the absence of any such cases for approximately 70 years. During this period of dengue outbreak, vector control using an insecticide was performed for Aedes albopictus at almost all areas where dengue virus transmission was suspected.

On March 28, 2015, an urgent symposium and public lecture was held in the 67th annual meeting of the Japan Society of Medical Entomology and Zoology by Professor Shigeto Yoshida, the President/Chairperson. Three scientists agreed to give a presentation in this meeting, which was titled "Autochthonous dengue outbreak in Japan after a blank of 70 years and the future prediction of such cases". Here their topics are published in this Journal, as part of a special issue. To ensure that an outbreak of dengue fever which will inevitably occur in Japan in the near future is better managed, it is important to understand the conditions underlying the autochthonous dengue outbreak in Japan in 2014. This program will provide a considerable amount of valuable information to all members of the Medical Entomology and Zoology.
\end{abstract}

Key words: dengue outbreak in Japan, Aedes albopictus

\section{はじめに}

デング熱は, 世界中の熱帯から亜熱帯の地域で広く流行 して抢り, 年間 1 億人近くの患者と約 25 万人の死亡者が発生 している（World Health Organization, 2015）。特に近年, 中南 米や東南アジア諸国で患者が増加しており, ブラジルでは 2013 年に 150 万人規模の流行が起こり, 2014年も 50 万人を 超える患者数が報告されている（World Health Organization, 2014). アジアでは, マレーシア, フィリピンで流行が継続 し, 特に中国と台湾では 2 万人前後の患者が発生しており, いずれも2014年の患者発生数は2013年を上回った.これら 隣国での大流行には，日本にも生息するヒトスジシマカが関 与したことも指摘された。一方，国内に扔けるデング熱の
輸入症例は, 2010 年以降毎年 200 例を超える患者数が報告さ れており（2011年は例外），2013年はこれまでの最高の 249 例, 2014 年の輸入症例は 179 例だが, 国内感染例 162 例を合 わせると合計で 341 例となる. 2015年は9月 12 日現在ですで に200例が報告されており（Fig. 1)，国内に持ち込まれるデ ングウイルスの量は年々増加していると言える.

\section{デング熱国内発生への準備}

デング熱の国内発生は, 1903 年に東京都で114名が発熱し た事例が最初かもしれない（谷・横河，1903）。その後沖縄 （1924年，1931年）と和歌山（1933年）でも流行し，1942年 から 1944 年までの 3 年間で西日本を中心に 20 万人規模の患 者数を記録したことはよく知られている（栗原，2015）。最 


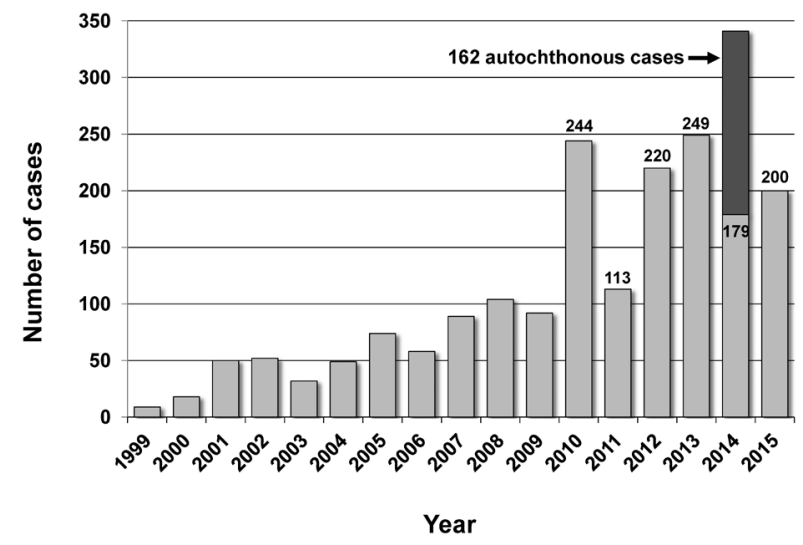

Fig. 1. Reported number of dengue cases in Japan since 1999. All cases are imported cases, except for 162 autochthonous cases reported in 2014. Data was modified from the website of Virology I of National Institute of Infectious Diseases. http://www0.nih.go.jp/vir1/NVL/NVL.html

後の国内感染例から 69 年後の 2013 年, 8 月中旬から下旬に かけて日本を旅行したドイツ人女性が帰国後に発熱しデン グ熱と診断された（Schmidt-Chanasit et al., 2014）。2013年に は，一時的にでもデング熱の感染源となり得るウイルス保有 者が日本国内に滞在していたのかもしれない。このデング熱 国内感染（疑い）例を受け，国立感染症研究所は「デング熱 国内感染事例発生時の対応・対策の手引き地方公共団体向け (案)」を翌2014年 4 月までに作成し，近い将来起きるかも知 れないデング熱の国内発生に備えた。ささに，西宮市役所環 境衛生課の協力の下，媒介蚊対策の模擬調査も実施された.

\section{4年のデング熱国内感染}

このような準備の中で迎えた 2014 年 8 月 27 日，代々木公 園で感染したと推測される症例がデング熱国内感染 1 例目と して厚生労働省から報道発表された. その後10月31日まで に合計 162 名の患者が報告されている（国立感染症研究所, 2015）. 都内の複数の公園では $\mathrm{CO}_{2}$ トラップや人囮法による 成虫密度の調查とウイルス検出が行われ，閉鎖措置が取られ た公園もあった．ウイルス保有蚊が高率に生息する公園が あったことも明らかになり, 推定感染地とされた公園や地域 のほとんどで殺虫剤を使用した蚊の駆除が行われた（関ら， 2015; Tanikawa et al., 2015). 殺虫剂が使用された多くの地域 では, 散布後の成虫密度は散布前に比べて顕著に低下してお り，概ねよい効果が得られたが（Tsuda et al., 2015），混乱が 生じた現場も少なくはなかった。戦後約 70 年の間, 日本人 の記憶に日本脳炎の文字はあるものの，デング熱はもとよ り，それ以外の蚊媒介感染症は外国でしか流行しない感染症 であるとする意識が日本全体に広まっていたのであろう。蚊 媒介感染症やその媒介蚊に対する知識が国民全体に不足して いた．また，個人情報を保護する意識が強く働き，推定感染 地や患者に関わる疫学情報を正しく，かつ早く知ることは困 難を極めた。約 70 年ぶりに経験したデング熱の国内感染例 は，我々に多くの課題を残して10月下旬に終息した.

\section{0 年前のデング熱流行との違い}

約 70 年前にもデング熱の国内流行があったことは上述し た。では，2014年の流行はそれとは何が違うのだろうか?
1942 年から 44 年にかけて, 南方戦地から物資を運ぶ船が 多数帰国したが，その船にデングウイルス保有者が含まれて いたことは想像に難くない。 また, 船内でネッタイシマカ が繁殖した例があったことも推察されており（堀田，1988）, 長旅の間にデングウイルスの感染サイクルが成立した船が 帰国し，その後 20 万人規模のデング熱患者をもたらしたと 考えられる，一方，2014年の国内感染者は162名であり，こ の数字が水山の一角だとしても，国内に持ち込まれたウイル ス量あるいはウイルス保有者は 70 年前より少ないかもしれ ない。しかし，2014年に日本を訪れた外国人観光客の数は 1,340 万人（出国日本人数は 1,600 万人)，2015 年は前年比を 大幅に上回っており（日本政府観光局，2015）, さらに政府 は2,000万人の誘致を目指すという。デング熱流行国への人 の行き来が活発になれば，国内でも感染リスクが高まること は明らかである.

1940 年代には日本脳炎やマラリアが西日本を中心に流行 し, 当時のデング熱の流行も大阪以西の地域で多くの患者を 出したことを考えると，少なくとも西日本における媒介蚊の 密度はかなり高かったと思われる。衛生昆虫対策にDDTや 合成ピレスロイド剤（アレスリン）が戦後ようやく普及した ことからも分かるように，当時は成虫対策に蚊取り線香が使 用されるだけであったが，一方で物理的な幼虫対策には多く の人が参加し熱心に行われていたという。2014年の関東地 方では，少なくともデング熱推定感染地とされた代々木公園 とその周辺地域の媒介蚊の密度は非常に高く, 70 年前の西 日本と変わらぬ密度，あるいはそれ以上に高い地域があった と思われる．しかし，一般市民の防蚊対策への関心は驚くほ ど低く，殺虫剤に対する違和感も依然として存在する．ま た，自治体による防蚊対策がほとんど整備されていなかった ことには失望した.

このように，国内でのデング熱感染リスクは高まる一方で あるが，拡大防止に貢献する法律がある１999年に施行され た法律「感染症法」によってデング熱が 4 類感染症に指定さ れた。感染症法は 1897 年に制定された「伝染病予防法」が 1999年に廃止となり，その内容を引き継ぐ形で新たに制定さ れた法律である。この措置によりデング熱の診断もより高い 精度で確定されるようになり，確定診断した医師はただちに 最寄りの保健所に届け出ることが義務づけられた．輸入症例 を含む患者の全数が把握され，患者への感染症の説明が徹底 し, 予防・治療薬は未だ市場には出ていないものの, 適切な 治療が施されるようになった。 デング熱の 4 類感染症への指 定は，デング熱流行の拡大防止に貢献していると言えよう.

\section{日本衛生動物学会での企画}

2015 年 3 月, 第 67 回日本衛生動物学会（金沢大会，吉田栄 人大会長) で上記タイトルでの緊急シンポジウム・市民講座 が企画された．様々な立場からデング熱対策に関わった 3 名 の専門家が本大会での情報提供を快く承諾してくださった。 忽那先生から国立国際医療センターでデング熱患者を診療さ れた経験からデング熱臨床の解説，島田先生から代々木公園 における積極的疫学調査の結果から2014年の国内発生の考 察, 津田先生から推定感染地とされた公園で実施した媒介蚊 調査に基づいた感染リスクの評価と媒介蚊対策について，そ れぞれご講演いただいた。ささらに，本特集記事へのご寄稿も 快諾していただいた。この記事が発行される12月には, 日 
本は昨年と同じ状況にあるのか，あるいは昨年来の対策が効 いてデング熱は流行していないのか. いずれにせよ，日本が すでにデング熱が毎年流行しても不思議ではない国と世界中 が認識していることは認めなければならない。抽らくは今 後も起きるであろうデング熱国内発生に備える上で, 本特集 記事が衛生動物学会員に貴重な資料となることは確かであ る.

\section{さいごに}

上述した「デング熱国内感染事例発生時の対応・対策の手 引き地方公共団体向け(案)」は，2014年 8 月 27 日のデング熱 国内発生例を受けて同年 9 月 12 日に第 1 版として厚生労働省 から参考配布され，さらに「デング熱診療ガイドライン（第 1版)」も9月16日に追加配布された。その時点でチクング 二ア熱の国内感染例は報告されていなかったが，デング熱と 媒介蚊の種類はほとんど同じとすることから，その後前者は 「デング熱・チクングニア熱等蚊媒介感染症の対応・対策の 手引き地方公共団体向け」に，後者は「デング熱・チクング ニア熱の診療ガイドライン」としてそれぞれ改定された。こ れに先立ち厚生労働省は，デング熱とチクングニア熱を重点 的な対策を講じる必要がある蚊媒介感染症と位置づけ，2015 年 4 月 28 日付けで「蚊媒介感染症に関する特定感染症予防指 針」を告示し適用した（厚生労働省，2015）。1999年に感染 症法が施行されて以降，インフルエンザ，結核，後天性免疫 不全症候群 (エイズ), 性感染症, 麻しん, 風疹を対象とし た予防指針が作成されており，デング熱・チクングニア熱を 主な対象とする蚊媒介感染症に関する予防指針はその 7 番目 となる．この指針の中には，平常時から媒介蚊の対策を行う こと, 国内感染例を迅速に把握すること, 発生時には的確な 媒介蚊の対策を行うこと, 患者に適切な医療を提供すること が重要であり, 蚊媒介感染症の対策の充実が喫緊の課題であ ると明記されている.

\section{謝辞}

第 67 回日本衛生動物学会での緊急シンポジウム・市民講座 開催の趣旨に賛同し，本雑誌特集記事として講演内容を寄稿 してくださった著者の皆さまに感謝致します，また，70年前 のデング熱流行を記述するにあたり，貴重なご意見をいただ いた国立感染症研究所の栗原 毅先生に御礼申し上げます.

\section{文献}

堀田 進. 1988. デング熱媒介蚁に関する一考察：19421944 年の日本内地のデング熱流行に打けるヒトスジシマ 力Aedes albopictus およびネッタイシマカAedes aegyptiの意 義について. 衛生動物, 49: 267-274.

厚生労働省. 2015. 蚊媒介感染症に関する特定感染症予防指 針。厚生労働省告示第 260 号.

国立感染症研究所。2015. 病原微生物検出情報（IASR）。デ ング熱報告例に関する記述疫学 (更新)（2014年 1 12月). [accessed August 13, 2015]. http://www.nih.go.jp/niid/ja/id/693disease-based/ta/dengue/idsc/iasr-news/5410-pr4211.html

栗原 毅. 2015. 日本列島のデング熱, 流行と媒介蚊. 遺 伝, 69: 411-414.

日本政府観光局（JNTO）. 2015. 統計データ（訪日外国人・ 出国日本人). [accessed August 13, 2015]. http://www.jnto.go. $\mathrm{jp} / \mathrm{jpn} /$ reference/tourism_data/visitor_trends/\#block0

Schmidt-Chanasit, J., Emmerich, P., Tappe, D., Gunther, S., Schmodt, S., Wolff, D., Hentschel, K., Sagebiel, D., Schoneberg, I., Stark, K. and Frank, C. 2014. Autochthonous dengue virus infection in Japan imported into Germany, September 2013. Euro Surveill. 19. pii: 20681.

関なおみ, 岩下裕子, 本 涼子, 神谷信行, 栗田雅行, 田 原なるみ，長谷川道弥，新開敬行，林 志直，貞升健志， 甲斐明美, 中島由紀子, 渡瀬博俊, 上田 隆, 前田秀雄, 小林一司，石崎泰江，広松恭子。2015。東京都に扔ける デング熱国内感染事例の発生について. 日本公衛誌， 62: 238-249.

谷 軍治郎，横河徳郎。1 1903. 歩兵第一連隊のデングェ熱に 就いて. 軍医学会雑誌, 137: 552-556.

Tanikawa, T., Yamauchi, M., Ishihara, S., Tomioka, Y., Kimura, G., Tanaka, K., Suzuki, S., Komagata, O., Tsuda, Y. and Sawabe, K. 2015. Operation note on dengue vector control against Aedes albopictus in Chiba City, Japan, where an autochthonous dengue case was confirmed in September 2014. Med. Entomol. Zool., 66: 31-33.

Tsuda, Y., Maekawa, Y., Ogawa, K., Itokawa, K., Komagata, O., Sasaki, T., Isawa, H., Tomita, T. and Sawabe, K. 2015. Biting density and distribution of Aedes albopictus during the September 2014 outbreak of dengue fever in Yoyogi Park and the vicinity in Tokyo Metropolis, Japan. Jpn. J. Infect. Dis., in press.

World Health Organization. 2015. Fact sheet Dengue and severe dengue [accessed August 13, 2015]. http://www.who.int/ mediacentre/factsheets/fs117/en/index.html

World Health Organization. 2014. Dengue: Dengue [accessed August 13, 2015]. http://www.paho.org/hq/index.php?option= com_topics\&view $=$ readall\&cid $=2158 \&$ Itemid $=40734 \&$ lang $=$ en 